Jurnal Health Sains: p-ISSN: 2723-4339 e-ISSN: 2548-1398

Vol. 2, No. 3, Maret 2021

\title{
FORMULASI SEDIAAN OBAT KUMUR DARI INFUSA DAUN SEREH WANGI (CYMBOPOGON WINTERIANUS JOWITT EX BOR)
}

\section{Alfi Sapitri dan Ulfayani Mayasari}

Universitas Sari Mutiara (USM) Medan Sumatera Utara, Indonesia

Email: alfi.syahfitri@gmail.com dan ulfayani.mayasari@gmail.com

\begin{tabular}{|c|c|}
\hline ARTIKEL INFO & ABSTRACT \\
\hline $\begin{array}{l}\text { Tanggal diterima: } 5 \text { Maret } 2021 \\
\text { Tanggal revisi: } 15 \text { Maret } 2021 \\
\text { Tanggal yang disetujui: } 25 \\
\text { Maret } 2021\end{array}$ & $\begin{array}{l}\text { The leaves of the fragrant lemongrass plant (Cymbogon } \\
\text { winterianus Jowitt ex Bor) contained alkaloids, saponins, } \\
\text { tannins, polyphenols, flavonoids and essential oils. The } \\
\text { purpose of this study was to determine the preparation of }\end{array}$ \\
\hline \begin{tabular}{ll} 
Keywords: & \\
infusion; & \multicolumn{2}{c}{ cymbopogon } \\
winterianus jowit ex bor; \\
streptococus mutan; candida \\
albicans
\end{tabular} & $\begin{array}{l}\text { mouthwash from fragrant lemongrass leaf infusion } \\
\text { against bacteria and fungi that cause dental caries, } \\
\text { namely Streptococcus mutans and Candida albicans } \\
\text { fungi. The research was experimental. The experiment } \\
\text { consisted of three repetitions with concentrations for } \\
\text { infusion of } 20 \% \text {, } 30 \%, 40 \%, 50 \% \text {, and } 60 \% \text { then the } \\
\text { concentration of fragrant lemongrass leaf infusion was } \\
\text { used as a mouthwash preparation to F0 (Base) F1 (50\%), } \\
\text { and F2 (60\%). Evaluation of mouthwash includes } \\
\text { examination of organoleptic, pH, stability, and viscosity. } \\
\text { The evaluation results showed that the physical properties } \\
\text { of the mouthwash preparation gave good results and met } \\
\text { the requirements for the mouthwash preparation. }\end{array}$ \\
\hline
\end{tabular}

\section{ABSTRAK}

Daun tanaman sereh wangi (Cymbogon winterianus Jowitt ex Bor) mengandung alkaloid, saponin, tanin, polifenol, flavonoid dan minyak atsiri. Tujuan dilakukannya penelitian ini untuk melihat sediaan obat kumur dari infusa daun sereh wangi terhadap bakteri dan jamur penyebab karies gigi yaitu Streptococcus mutans dan jamur Candida albicans. Jenis penelitian yang digunakan adalah eksperimental. Percobaan terdiri tiga kali pengulangan dengan konsentrasi untuk infusa 20\%, 30\%, $40 \%, 50 \%$ dan $60 \%$, kemudian konsentrasi infusa daun sereh wangi dijadikan sediaan obat kumur menjadi F0 (Basis) F1 (50\%), dan F2 (60\%). Evaluasi obat kumur

\section{Kata Kunci:}

infusa; cymbopogon winterianus jowit ex bor; streptococus mutans; candida albicans meliputi pemeriksaan organoleptis, $\mathrm{pH}$, stabilitas, dan viskositas. Hasil evaluasi menunjukkan bahwa sifat fisik sediaan obat kumur memberikan hasil yang baik dan memenuhi syarat sediaan obat kumur.

Coresponden Author:

Email: alfi.syahfitri@gmail.com Artikel dengan akses terbuka dibawah lisensi 


\section{Pendahuluan}

Sampai saat ini, karies dan penyakit periodontal merupakan masalah kesehatan mulut yang banyak dikeluhkan masyarakat (Wijayanti, 2010). Salah satu penyakit mulut yang sering dialami masyarakat adalah karies gigi. Bakteri yang paling sering menyebabkan karies gigi adalah Streptococcus mutans. Bakteri ini dapat membentuk plak dengan cara mensintesis sukrosa yang berikatan dengan mikroorganisme yang melekat pada permukaan gigi yang keras (M. Yuliana et al., 2016).

Bakteri-bakteri yang berada pada rongga mulut yaitu bakteri Streptococcus mutans, Staphylococcus aureus, Lactobacillus $s p$, Escherichia coli, bakteri-bakteri tersebut memiliki peran penting dalam penyakit karies gigi (Hoshino et al., 2012). Bakteri yang ditemukan dalam jumlah besar pada plak penderita karies adalah Streptococcus mutans (Hakim \& Editia, 2018). Streptococcus mutans di dalam rongga mulut menghasilkan permukaan asam dengan menurunkan $\mathrm{pH}$ menjadi 5,5 atau lebih rendah yang membuat email mudah larut kemudian terjadi penumpukan bakteri sehingga terbentuknya karies gigi, selain itu di dalam rongga mulut terdapat kolonisasi ragi yang tumbuh yaitu Candida albicans (Alfath.C.R, 2013).

Karies gigi dapat dikurangi dengan menekan pertumbuhan bakteri Streptococcus mutans di dalam rongga mulut khususnya pada plak gigi dan saliva, yaitu dengan memanfaatkan bahan-bahan alami yang mengandung senyawa bioaktif. Salah satu cara untuk mencegah karies gigi dan bau mulut yaitu dengan menggunakan obat kumur (mouthwash) yang mengandung bahan antibakteri.

Tanaman yang memiliki khasiat sebagai antimikroba adalah tanaman sereh wangi (Cymbopogon winterianus Jowitt ex Bor) (Yuliana, 2016). Kandungan kimia dari sereh wangi adalah minyak atsiri, saponin, polifenol, dan flavonoid (Bassolé et al.,
2011). Senyawa metabolit sekunder sereh wangi memiliki aktivitas antimikroba yang diharapkan menjadi alternatif pengobatan tradisional untuk penyakit yang disebabkan oleh bakteri dan jamur (Puspawati et al., 2016), sehingga kandungan senyawa aktif tersebut, mengindikasikan sereh memiliki aktivitas antibakteri yang cukup besar (Jafarian et al., 2012). Tanaman sereh mengandung senyawa saponin. Senyawa tersebut terbukti efektif menghambat pertumbuhan bakteri (Astuti, 2019).

Daun sereh juga mengandung banyak minyak atsiri yang mengandung senyawa manoterpene seperti sitral dan geraniol secara umum kandungan sereh terdiri dari kariofilen bersifat anti bakteri, antifungi anti inflamasi, antitumor dan dapat digunakan sebagai obat bius. Sitarl berifat antihistamin dan antiseptik. Selain itu, (Lamlertthon et al., 2007) memaparkan bahwa kandungan sitronellal, geraniol, dan sitronellol dalam minyak sereh wangi juga mampu menghambat aktivitas bakteri.

Menurut Penelitian (Yuliana, 2016) formulasi sediaan mouthwash yang mengandung minyak serai wangi. Minyak serai wangi dengan konsentrasi $0,5 \%$ memiliki aktivitas antibakteri terhadap bakteri Streptococcus mutans dengan diameter hambat $13,45 \pm 0,071 \mathrm{~mm}$. Formula akhir sediaan mouthwash yang dibuat dengan formula minyak sereh wangi $0,5 \%$; sodium lauril sulfat $2 \%$; natrium benzoat $0,1 \%$; sorbitol 20\%; mentol $0,1 \%$; dan gliserin $5 \%$ menghasilkan sediaan yang stabil berdasarkan pengujian organoleptik dan viskositas selama 28 hari dan sediaan mouthwash minyak serai wangi dengan konsentrasi $0,5 \%$ dan sorbitol $20 \%$ memiliki aktivitas antibakteri terhadap Streptococcus mutans dengan diameter hambat 31,2 $\pm 0,53 \mathrm{~mm}$.

Berdasarkan uraian di atas, maka dilakukanlah penelitian tentang potensi sereh wangi sebagai salah satu antimikroba dari bahan alam untuk pembuatan sediaan obat 
kumur antimikroba dalam bentuk infusa untuk menghambat pertumbuhan bakteri Streptococcus mutans, dan jamur Candida albicans.

\section{Metode Penelitian}

Jenis penelitian ini adalah penelitian eksperimental dimana peneliti memberikan perlakuan terhadap bakteri Streptococcus mutans dan jamur Candida albicans dalam berbagai konsentrasi kemudian dibuat formulasi obat kumur sediaan infusa dari daun sereh wangi. Penelitian meliputi pengumpulan bahan tumbuhan, identifikasi tumbuhan, pembuatan simplisia, karakterisasi simplisia, Pembuatan infusa daun sereh wangi, pengujian infusa daun sereh wangi terhadap bakteri dan jamur yang dilakukan dengan metode difusi cakram pada bakteri Streptococcus mutans (ATCC 25175) dan Candida albicans (ATCC 10231).

\section{Pembuatan Infusa Daun Sereh Wangi (Cymbopogon winterianus Jowitt ex Bor)}

Menurut Farmakope Indonesia Edisi III, infusa merupakan sediaan cair yang dibuat dengan mengekstraksi (menyari) simplisia nabati dengan air pada suhu $90^{\circ} \mathrm{C}$ selama 15 menit.

Pembuatan infusa daun sereh wangi dilakukan dengan cara mencampur simplisia dengan kehalusan yang sesuai dengan air secukupnya, yaitu diambil 5 gram serbuk dilarutkan pada 1 liter air, panaskan di atas tangas air selama 15 menit terhitung mulai suhu mencapai $90^{\circ} \mathrm{C}$ sambil sesekali diaduk. Serkai selagi panas melalui atau dengan menggunakan kain flanel, serta tambahkan air panas secukupnya melalui ampas hingga diperoleh volume infus.

\section{Hasil dan Pembahasan}

\section{A. Hasil Penelitian}

\section{Aktivitas Antibakteri Infusa Daun Sereh Wangi Terhadap Streptococcus mutans}

Hasil uji aktivitas antibakteri menunjukkan bahwa Infusa daun sereh wangi dapat menghambat pertumbuhan Bakteri Streptococcus mutans semakin tinggi konsentrasi akan menghasilkan diameter daerah hambat yang semakin besar (Hidayat \& Tri, 2019). Hal ini membuktikan peningkatan konsentrasi infusa sereh wangi memiliki kolerasi positif terhadap peningkatan diameter zona hambat terhadap bakteri Streptococcus mutans. Hasil pengukuran diameter daerah hambat infusa daun sereh wangi dapat dilihat pada Tabel 1 sebagai berikut:

Tabel 1

Hasil Diameter Zona Hambat Pertumbuhan Bakteri Streptococcus mutans

\begin{tabular}{|c|c|c|c|c|}
\hline \multirow[t]{2}{*}{$\begin{array}{l}\text { Konsentrasi } \\
\text { Infusa DSW }\end{array}$} & \multicolumn{3}{|c|}{$\begin{array}{c}\text { Diameter Zona Hambat } \\
(\mathbf{m m})\end{array}$} & \multirow{2}{*}{$\begin{array}{c}\text { Zona } \\
\text { Hambat } \\
\text { Rata-Rata }\end{array}$} \\
\hline & P1 & P2 & P3 & \\
\hline 60 & 15,4 & 15,9 & 15,6 & $15,7 \pm 0,17$ \\
\hline 50 & 14,9 & 14,7 & 14,6 & $14,73 \pm 0,17$ \\
\hline 40 & 14,1 & 13,8 & 13,8 & $13.9 \pm 0,17$ \\
\hline 30 & 12,8 & 12,5 & 12,7 & $12,67 \pm 0,15$ \\
\hline 20 & 10,8 & 10,4 & 10,9 & $10,67 \pm 0,25$ \\
\hline Amoksisilin & & 27,5 & & $27,5 \pm 0,0$ \\
\hline Aquadest & & 0 & & $\mathbf{0}$ \\
\hline
\end{tabular}

Hasil uji aktiktifitas antibakteri (Tabel 1) yang diamati selama $1 \times 24$ jam menunjukkan bahwa pada zona hambat yang terjadi pada pertumbuhan Streptococcus mutans tampak berbeda-beda dari masingmasing perlakuan, hal ini dapat dilihat pada tabel 1 di atas. Zona hambat terkecil adalah pada konsentrasi $20 \%$ dengan rata-rata diameter zona hambatnya sebesar $10,67 \mathrm{~mm}$ dan zona hambat yang terbesar adalah konsentrasi $60 \%$ dengan rata-rata diameter zona hambatnya sebesar $15,7 \mathrm{~mm}$. Hal ini menunjukkan bahwa tingkat penghambatan pertumbuhan bakteri Streptococcus mutans oleh infusa daun sereh wangi mengalami 
kenaikan dari perlakuan konsentrasi $20 \%$ sampai $60 \%$. Pada tabel 1 . Hasil pengukuran diameter zona hambat pertumbuhan bakteri Streptococcus mutans oleh infusa daun sereh wangi di atas menunjukkan bahwa pada konsentrasi $60 \%$, rata-rata zona hambatnya sebesar 15,7 mm, konsentrasi $50 \%$ zona hambatnya sebesar $14,73 \mathrm{~mm}$, konsentrasi $40 \%$ rata-rata zona hambatnya sebesar 13,9 $\mathrm{mm}$, konsentrasi $30 \%$ rata-rata zona hambatnya sebesar $12,67 \mathrm{~mm}$, dan pada konsentrasi $20 \%$ rata-rata zona hambatnya sebesar $10,67 \mathrm{~mm}$.

Berdasarkan pada data diameter zona hambat maka dapat dilihat bahwa diameter zona hambat semakin meningkat dengan adanya peningkatan konsentrasi. Hal ini membuktikan bahwa peningkatan konsentrasi infusa daun sereh wangi memiliki korelasi positif terhadap peningkatan diameter zona hambat pertumbuhan bakteri Streptococcus mutans. Aktivitas antibakteri dapat disebabkan adanya kandungan senyawa kimia yaitu tanin, saponin, dan flavonoida (Udawaty, W., Yusro, F., dan Sisilli, 2019).

Pada konsentrasi 50\% dan 60\% efektif digunakan sebagai antibakteri. Batas daerah hambat dinilai efektif apabila memiliki diameter daya hambat lebih kurang $14 \mathrm{~mm}$ sampai $16 \mathrm{~mm}$ (Dirjen, 1995).

2. Aktivitas Antifungi Infusa Daun Sereh Wangi Terhadap Candida albicans

Hasil uji Aktivitas antijamur menunjukkan bahwa infusa daun sereh wangi dapat menghambat pertumbuhan Jamur Candida albicans.
Tabel 2

Hasil Diameter Zona Hambat Pertumbuhan Jamur Candida albicans

\begin{tabular}{ccccc}
\hline \multirow{2}{*}{$\begin{array}{c}\text { Konsentrasi } \\
\text { Infusa DSW }\end{array}$} & \multicolumn{3}{c}{$\begin{array}{c}\text { Diameter Zona } \\
\text { Hambat }(\mathbf{m m})\end{array}$} & $\begin{array}{c}\text { Zona } \\
\text { Hambat } \\
\text { Rata-Rata }\end{array}$ \\
\cline { 2 - 4 } & P1 & P2 & P3 & Rata \\
\hline 60 & 15,1 & 14,9 & 15,0 & $15,0 \pm 0,10$ \\
\hline 50 & 14,7 & 14,5 & 14,9 & $14,7 \pm 0,2$ \\
\hline 40 & 13,8 & 13,8 & 14,0 & $13,6 \pm 0,11$ \\
\hline 30 & 12,0 & 12,4 & 12,4 & $11,9 \pm 0,23$ \\
\hline 20 & 10,4 & 10,6 & 10,7 & $10,3 \pm 0,15$ \\
\hline Ketokonazol & \multicolumn{5}{c}{25,6} & $25,6 \pm 0$ \\
\hline Aquadest & 0 & 0 \\
\hline
\end{tabular}

Hasil uji aktivitas antijamur (Tabel 2) diamati selama $2 \times 24$ jam menunjukkan bahwa adanya zona hambat pada konsentrasi 60\%, 50\%, $40 \%, \quad 30 \%$ dan 20\%. Pada pengulangan pertama, kedua, dan ketiga, konsentrasi $60 \%$ memiliki zona hambat rata-rata $15,0 \mathrm{~mm}$. Pada konsentrasi $50 \%$ memiliki zona hambat rata-rata $14,7 \mathrm{~mm}$. Pada konsentrasi $40 \%$ memiliki zona hambat rata-rata $13,6 \mathrm{~mm}$. Pada konsentrasi $30 \%$ memiliki zona hambat rata-rata $11,6 \mathrm{~mm}$ dan $20 \%$ zona hambat rata-rata sebesar 10,03. Pada kontrol positif memberikan zona hambat yang jauh lebih besar yaitu 25,6 mm, dan pada kontrol negatif sama sekali tidak menunjukkan adanya zona hambat.

Hal ini membuktikan bahwa peningkatan konsentrasi terhadap infusa daun sereh wangi memiliki korelasi positif terhadap peningkatan diameter zona hambat pertumbuhan bakteri Streptococcus mutans dibandingkan dengan jamur Candida albican. Aktivitas antimikroba dapat disebabkan karena adanya kandungan senyawa metabolit sekunder yaitu saponin, flavonoid, alkaloid, tannin dan steroid. Saponin dapat mengakibatkan sel mikroba lisis yaitu dengan menggagu stabilitas membran selnya. Saponin bersifat sebagai 
surfaktan yang terbentuk polar akan menurunkan tegangan permukaan membran sterol dari dinding sel Candida albicans, sehingga menyebabkan gangguan permeabilitas membran yang berakibat pemasukan bahwa atau zatzat yang diperlukan dapat tergaggu sehingga akhirnya membengkak dan pecah. Berdasarkan penelitian (Fitriani et al., 2020), kandungan kimia yang terdapat dalam sereh wangi ini dapat menghambat pertumbuhan jamur Candida albicans yaitu senyawa saponin, tanin, dan flavonoid, hasil diameter zona hambat masing-masing $25 \%$ (16,5 mm), $50 \%$ (18,6 mm), $75 \%(23,7 \mathrm{~mm}), 100 \%$ $(21,4 \mathrm{~mm})$.

\section{Formulasi Sediaan Obat Kumur}

Pembuatan sediaan obat kumur dari infusa daun sereh wangi dengan konsentrasi $50 \%$ dan $60 \%$. Komposisi formula mouthwash (Yuliana, 2016). Infusa daun sereh wangi dijadikan sediaan obat kumur menjadi tiga formula yaitu F0 (basis), F1 (80\%), F2 (100\%). Evaluasi obat kumur meliputi pemeriksaan organoleptis, $\mathrm{pH}$, stabilitas, dan viskositas. Formulasi mouthwash menggunakan sorbitol, gliserin, sakarin, peppermint oil, nipagin dan aquadest. dapat dilihat pada tabel 3 .

Tabel 3

Formulasi Sediaan Obat Kumur

\begin{tabular}{cccc}
\hline Bahan & F 0 & FI & F II \\
\hline Infusa DSW & 0 & $50 \%$ & $60 \%$ \\
\hline Sorbitol & $5 \%$ & $5 \%$ & $5 \%$ \\
\hline Gliserin & $5 \%$ & $5 \%$ & $5 \%$ \\
\hline Sakarin $(\mathrm{g})$ & $0,2 \%$ & $0,2 \%$ & $0,2 \%$ \\
\cline { 1 - 2 } Peppermintoil & $0,2 \%$ & $0,2 \%$ & $0,2 \%$ \\
\cline { 1 - 2 } Nipagin & $0,1 \%$ & $0,1 \%$ & $0,1 \%$ \\
\cline { 1 - 1 } Aquadest ad & $100 \mathrm{ml}$ & $\underline{100 \mathrm{ml}}$ & $\underline{100 \mathrm{ml}}$
\end{tabular}

\section{B. Pembahasan}

1. Hasil Evaluasi Formulasi Sediaan Obat kumur

a. Hasil Pemeriksaan Stabilitas Sediaan

Parameter yang diamati dalam pemeriksaan stabilitas sediaan obat kumur ini meliputi perubahan bentuk, warna, aroma dan rasa. Penelitian terkait sediaan dilakukan oleh (Yuliana, 2016) yaitu dengan meneliti formulasi sediaan obat kumur dari minyak sereh wangi. Sediaan obat kumur dari infusa daun sereh wangi tidak mengalami perubahan bentuk, warna, aroma dan rasa. Pada F0 bentuk sediaan tetap dalam kondisi cair, warna putih bening, aroma tetap stabil yaitu spesifik mint dan rasa manis. Formula I bentuk cair, warna coklat muda, aroma khas sereh dan rasa manis, pada formula II bentuk cair, warna coklat tua, aroma khas sereh dan rasa manis selama 28 hari penyimpanan

Hasil uji pemeriksaan stabilitas sediaan obat kumur dalam pengamatan perubahan bentuk, warna, aroma, dan rasa menunjukan bahwa seluruh sediaan yang dibuat tetap stabil dari segi bentuk, warna, aroma, dan rasa yang disimpan selama 28 hari dan sediaan disimpan dalam keadaan tertutup.

\section{b. Hasil Penentuan pH Sediaan}

Penentuan $\mathrm{pH}$ sediaan obat kumur ini dilakukan selama 28 hari pengamatan. Hasil pengukuran $\mathrm{pH}$ menunjukan bahwa sediaan yang dibuat dari infusa daun sereh wangi dengan konsentrasi $50 \%$ dan $60 \%$ tidak jauh berbeda pada suhu $40^{\circ} \mathrm{C}$. FI 
dan FII rata-rata yaitu $\mathrm{pH}$ 6,23 dan 6,32. Nilai $\mathrm{pH}$ obat kumur yang dihasilkan harus berada pada rentang $\mathrm{pH}$ rongga mulut yang berkisar antara 5,5 - 7,9 (Aziz et al., 2015) sehingga pada saat sediaan dikonsumsi tidak menimbulkan iritasi pada mukosa mulut.

\section{c. Viskositas Sediaan}

Viskositas adalah indeks hambatan aliran cairan, viskositas dapat diukur dengan mengukur laju alir yang melalui tabung berbentuk silinder. Viskositas ini juga disebut sebagai kekentalan suatu zat. Makin kental suatu zat cairan, makin besar gaya yang dibutuhkan untuk membuatnya mengalir pada kekentalan tertentu (Handayani, F., Warnida, H., dan Nur, 2016). Pengukuran nilai viskositas obat kumur infusa daun sereh wangi dilakukan dengan menggunakan viskometer oswaltd. Hasil dari pengukuran viskositas obat kumur menunjukan satuan kekentalan medium pendispersi dari sebuah larutan, pengukuran viskositas dari ketiga formula menunjukan bahwa sediaan obat kumur memiliki viskositas F0 sebesar 1,25 cPs, FI sebesar 1,31275 cPs viskositas FII sebesar 1,4867 cPs. Perbedaan nilai viskositas yang didapat diakibatkan karena semakin besar nilai bobot jenis suatu cairan semakin tinggi pula viskositasnya.

d. Aktivitas Sediaan Obat Kumur Infusa Daun Sereh Wangi

Hasil uji aktivitas sedian obat kumur infusa daun sereh wangi pada F0, formula I dan formula 2 dengan metode difusi agar menggunakan kertas cakram terhadap bakteri Streptococcus mutans dan jamur Candida albicans.

Tabel 6

Sediaan Obat Kumur Pada Streptococcus mutans

\begin{tabular}{|c|c|c|c|c|}
\hline \multirow[t]{2}{*}{$\begin{array}{c}\text { Sediaan } \\
\text { Obat Kumur }\end{array}$} & \multicolumn{3}{|c|}{$\begin{array}{l}\text { Diameter Zona } \\
\text { Hambat (mm) }\end{array}$} & \multirow{2}{*}{$\begin{array}{c}\text { Zona } \\
\text { Hambat } \\
\text { Rata-Rata }\end{array}$} \\
\hline & $\overline{\text { P1 }}$ & P2 & P3 & \\
\hline F0 & 0 & 0 & 0 & 0 \\
\hline FI & 14,3 & 14,1 & 14,5 & $14,3 \pm 0,2$ \\
\hline FII & 15,7 & 15,9 & 15,5 & $15,7 \pm 0,2$ \\
\hline Kontrol (+) & \multicolumn{3}{|c|}{25,6} & $25,6 \pm 0$ \\
\hline
\end{tabular}

Tabel 7

Sediaan Obat Kumur Pada Candida albicans

\begin{tabular}{ccccc}
\hline $\begin{array}{c}\text { Sediaan } \\
\text { Obat } \\
\text { Kumur }\end{array}$ & \multicolumn{3}{c}{$\begin{array}{c}\text { Diameter Zona } \\
\text { Hambat }(\mathbf{m m})\end{array}$} & $\begin{array}{c}\text { Zona } \\
\text { Hambat } \\
\text { Rata-Rata }\end{array}$ \\
\cline { 2 - 4 } & P1 & P2 & P3 & 0 \\
\hline F0 & 0 & 0 & 0 & $13,7 \pm 0,2$ \\
\hline FI & 13,7 & 13,5 & 13,9 & $14,07 \pm$ \\
FII & 14,2 & 14,1 & 13,8 & 0,15 \\
\hline Kontrol (+) & & 18,4 & & $18,4 \pm 0$ \\
\hline
\end{tabular}

Dari tabel 6 dan tabel 7. Hasil uji aktivitas sediaan obat kumur infusa daun sereh wangi terhadap Streptococcus mutans, bahwa formula I (FI) sediaan obat kumur dengan konsentrasi $50 \%$ memiliki rata-rata diameter zona hambat sebesar 14,3 mm dan terhadap Candida albicans sebesar $13,7 \mathrm{~mm}$. Formula II (FII) sediaan obat kumur dengan konsentrasi 60\% terhadap Streptococcus mutans memiliki rata-rata diameter zona hambat sebesar $15,7 \mathrm{~mm}$ dan terhadap Candida albicans sebesar 14,07 mm. Penggunaan kontrol positif berupa mouthwash herbal dengan produk Total care herbal pada bakteri memiliki zona hambat 25,6 $\mathrm{mm}$ dan pada jamur 18,4 $\mathrm{mm}$.

Pada bakteri Streptococcus mutans diperoleh diameter zona hambat lebih besar dibanding pada jamur Candida albicans ini disebabkan karena kandungan kimia yang terdapat dalam infusa dari daun sereh wangi. Hal ini disebabkan Streptococcus 
mutans memiliki struktur selubung sel yang relatif sederhana dan bakteri gram positif ini lebih rentan terhadap antimicrobial (Sakinah et al., 2018).

Pengujian sediaan obat kumurkumur air perasan daun sereh wangi pada FI dan FII memberikan zona hambat yang efektif terhadap bakteri dan jamur uji yaitu lebih besar dari 14 $\mathrm{mm}$ terhadap bakteri Streptococcus mutans dan jamur Candida albicans. Menurut (Dirjen, 1995), suatu zat dikatakan memiliki daya hambat yang memuaskan dengan diameter daerah hambatan lebih kurang $14 \mathrm{~mm}$ sampai dengan $16 \mathrm{~mm}$. Jadi sediaan obat kumur-kumur pada formula I (FI) dan formula II (FII) yang mengandung air perasan daun sereh wangi $30 \%$ dan 40\% memenuhi persyaratan Ditjen POM (1995).

Penelitian tentang infusa juga di teliti oleh (Yulistianti, 2015), hasil penelitian menunjukkan air rebusan daun sirih merah dengan konsentrasi $5 \%$ mempunyai daya hambat sebesar $9,2 \mathrm{~mm}$, air rebusan daun sirih merah dengan konsentrasi $10 \%$ mempunyai daya hambat sebesar $7,77 \mathrm{~mm}$, air rebusan daun sirih merah dengan konsentrasi $15 \%$ mempunyai daya hambat sebesar $7,073 \mathrm{~mm}$, air rebusan daun sirih merah dengan konsentrasi $20 \%$ mempunyai daya hambat sebesar $10,105 \mathrm{~mm}$.

\section{Kesimpulan}

Hasil uji aktivitas antimikroba sediaan obat kumur dari infusa daun sereh wangi (Cymbopogon winterianus Jowitt ex Bor.) mempunyai efektifitas terhadap bakteri Streptococcus mutans pada Formulasi I (50\%) dan Formulasi II (60\%) dengan zona hambat masing-masing yaitu $14,3 \mathrm{~mm}$ dan $15,7 \mathrm{~mm}$, dan pada jamur Candida albicans pada Formulasi I (50\%) dan Formulasi II (60\%) dengan zona hambat masing-masing yaitu $13,7 \mathrm{~mm}$ dan $14,07 \mathrm{~mm}$ secara in vitro. Pembuatan sediaan obat kumur diformulasikan dengan konsentrasi 50\% (FI) dan konsentrasi $60 \%$ (FII) memiliki kestabilan baik selama penyimpanan 28 hari. Kesimpulan dari penelitian ini adalah perbedaan konsentrasi air rebusan daun sirih merah mempunyai pengaruh sebagai daya hambat terhadap pertumbuhan bakteri Streptococcus mutans. Air daun sirih merah lebih berpengaruh terhadap kesehatan gigi dan mulut.

\section{BIBLIOGRAFI}

Alfath.C.R, Y. V. Da. S. (2013). Antibakterial Effect Of Graniti Fructus Cortex Extract On Streptococcus Mutans In Vitro. Journal Of Dentristy Indonesia, 1(20), 58.

Astuti, R. (2019). Uji Efektivitas Ekstrak Kulit Jengkol (Pithecellobium Jiringa) Sebagai Biofungisida Terhadap Penyebab Penyakit Layu Fusarum (Fusarium Oxysporum), Antraknosa (Colletotrichum Capsici) Dan Bercak Daun (Cercospora Capsici) Pada Tanaman Cabai Merah (Capsicum Annum L.) Secara In-Vitro. Universitas Medan Area.

Aziz, N., Faraz, M., Pandey, R., Shakir, M., Fatma, T., Varma, A., Barman, I., \& Prasad, R. (2015). Facile Algae-Derived Route To Biogenic Silver Nanoparticles: Synthesis, Antibacterial, And Photocatalytic Properties. Langmuir, 31(42), 11605-11612.

Bassolé, I. H. N., Lamien-Meda, A., Bayala, B., Obame, L. C., Ilboudo, A. J., Franz, C., Novak, J., Nebié, R. C., \& Dicko, M. H. (2011). Chemical Composition And Antimicrobial Activity Of Cymbopogon Citratus And Cymbopogon Giganteus Essential Oils Alone And In Combination. Phytomedicine, 18(12), 1070-1074.

Dirjen, P. O. M. (1995). Farmakope Indonesia Edisi Iv. Departemen Kesehatan 
Republik Indonesia, Jakarta, 7.

Fitriani, S., Nurdin, M. M., Ramadhanti, H. A., Subekti, I., Nurhasanah, N., \& Yusup, I. F. (2020). Pembentukan Dan Pelatihan Duta Anti Rokok Pada Komunitas Saka Bakti Husada Di Smk Kesehatan X Kota Tasikmalaya Tahun 2019. Jurnal Abdimas Kesehatan Tasikmalaya, 2(02), 47-51.

Hakim, R. F., \& Editia, A. (2018). Pengaruh Air Perasan Jeruk Nipis (Citrus Aurantifolia) Terhadap Pertumbuhan Bakteri Lactobacillus Acidophilus. Journal Of Syiah Kuala Dentistry Society, 1(3), 1-5.

Handayani, F., Warnida, H., Dan Nur, J. . (2016). Fomulasi Dan Uji Aktivitas Antibakteri Streptococcus Mutan Dari Sediaan Moutwash Eksrtrak Daun Salam (Syzygium Polyanthum (Wight) Walp). Asi Samarinda. Akademi Farm.

Hidayat, M., \& Tri, I. (2019). Identifikasi Pola Makan Pada Pasien Hipertensi Di Dusun Lasah Desa Tawangargo Kecamatan Karangploso. University Of Muhammadiyah Malang.

Hoshino, A., Saitoh, M., Oka, A., Okumura, A., Kubota, M., Saito, Y., Takanashi, J., Hirose, S., Yamagata, T., \& Yamanouchi, H. (2012). Epidemiology Of Acute Encephalopathy In Japan, With Emphasis On The Association Of Viruses And Syndromes. Brain And Development, 34(5), 337-343.

Jafarian, J. H., Al-Shaer, E., \& Duan, Q. (2012). Openflow Random Host Mutation: Transparent Moving Target Defense Using Software Defined Networking. Proceedings Of The First Workshop On Hot Topics In Software Defined Networks, 127-132.

Lamlertthon, S., Luangnarumitchai, S., \& Tiyaboonchai, W. (2007). Antimicrobial Activity Of Essentials Oils Against Five Strains Of Propionibacterium Acnes. Mahidol University Journal of
Pharmaceutical Sciences, 34(1-4), 6064.

Puspawati, N. M., Suirta, I. W., \& Bahri, S. (2016). Isolasi, Identifikasi, Serta Uji Aktivitas Antibakteri Pada Minyak Atsiri Sereh Wangi (Cymbopogon Winterianus Jowitt). Jurnal Kimia (Journal Of Chemistry).

Sakinah, N., Dwyana, Z., Tambaru, E., \& Rante, H. (2018). Uji Aktivitas Sediaan Obat Kumur Ekstrak Daun Miana Coleus Scutellarioides (L.) Benth Terhadap.

Udawaty, W., Yusro, F., Dan Sisilli, S. (2019). Identifikasi Senyawa Kimia Minyak Sereh Wangi Klon G3 (Cymbopogon Nardus L.) Dengan Media Tanam Tanah Gambut Dan Potensinya Sebagai Antibakteri Enterococus Faecalis. Jurnal Ilmu Kehutanan, 9(2).

Wijayanti, R. Y. (2010). Pengaruh Kepemimpinan, Motivasi, Dan Komitmen Organisasi Terhadap Kinerja Pns Di Lingkungan Organisasi Dinas Pendidikan Kabupaten Kudus. Analisis Manajemen, 4(2), 137-153.

Yuliana, Et Al. (2016). Mouthwash Mengandung Minyak Serai Wangi (Cymbopongon Winterianus Jowitt) Serta Uji Aktivitas Pada Bakteri Streptococcus Mutans. Prosiding Farmasi, 2, 2.

Yuliana, M., Darma, G. C. E., \& Priani, S. E. (2016). Formulasi Sediaan Mouthwash Mengandung Minyak Serai Wangi (Cymbopogon Winterianus Jowitt) Serta Uji Aktivitasnya Pada Bakteri Streptococcus Mutans. Universitas Islam Bandung.

Yulistianti, D. (2015). Pengaruh Perbedaan Konsentrasi Air Rebusan Daun Sirih Merah Terhadap Daya Hambat Pertumbuhan Bakteri Streptococcus Mutans. Jurnal Kesehatan Gigi, 2(1). 